\section{Premises and recruitment experts on hand}

Armed with years of experience and knowledge about the dental profession, MediEstates and MediCruit will be at the BDIA Dental Showcase 2018, ready to advise and answer questions on buying and selling a practice and finding the perfect dental job-candidate match.

MediEstates has grown to become the largest specialist broker of dental practices in the UK. Its experienced team can help practice owners optimise the value of their practice, and potential buyers find the ideal business to suit their experience and aspirations.

With more than 4,000 interested buyers just waiting for the right practice, and an array of tools and resources on hand to help actively market more than 110 dental practices at any one time, MediEstates is best placed to achieve a successful outcome for buyers and sellers alike.

Whether you're job hunting or recruiting, MediCruit is the UK's largest dental jobs agency, successfully matching candidates with their perfect job for more than 17 years.

The firm specialises solely in dental with in-depth knowledge of every position within a dental practice and has a proven track record of success backed by expert consultants, industry-leading partners and cutting-edge systems and technology.

With more than 65,000 candidates in its database, its 24/7 Online Candidate Search makes conducting an initial online search, using tailored filters, and CV requests, easy and stress-free.

Experienced consultants at MediEstates and MediCruit are able to speak to dentists, practice managers and those searching for a new role in the profession, and where better than this year's BDIA Dental Showcase?

Come and visit the two firms on Stand H16 at the BDIA Dental Showcase 2018.

\section{Leading edge imaging equipment}

Dürr Dental's brand is synonymous with leading edge imaging equipment. Their panoramic device is so easy to use you won't need a second take, as the first one will almost certainly be perfect.

Unlike other devices, it does not rely on experience or expertise, in fact both are almost negligible.

Learn how the latest networking systems can be used with your compressor and suction system. By linking them to the network, practices can see the performance of equipment at a glance. Linking the compressor, for example, to the digital network yields numerous benefits - current status, faults or messages, such as for filter changes, are immediately displayed.

Launched in 2018, and available to try at the BDIA Dental Showcase 2018, is Lunos, the premium prophylaxis system, which includes the innovative MyFlow powder jet handpiece, with its unique exchangeable chamber, meaning powder containers can be replaced quickly and easily.

Come and visit Dürr Dental at the Dental Showcase at Stand L50 or visit https://www.duerrdental.com/en/contact/ branchoffices-representations/europe/Great\%20Britain/.

\section{Magnificent magnification service on show}

For first class magnification equipment with a reputation for quality and performance, visit Nuview on stand L25 at the upcoming BDIA Dental Showcase 2018.

Nuview will be exhibiting a range of Carl Zeiss solutions, including the EyeMag Pro and EyeMag Smart loupes and EXTARO 300 dental microscope, giving professionals the chance to try before they buy.

To complete the experience, the team will be providing expert advice, demonstrations and loupes fitting and measuring over the course of the three-day event.

Any professional interested in switching to non-alcohol disinfection and cleaning products should also swing by Stand L25, as Nuview's own water-based Continu range will be on display too.

Delegates can expect to see a number of products this year, including the ever-popular Disinfectant for Dental Unit Waterlines and new Cleaning \& Disinfectant Wipes for Loupes.

More information is available by calling Nuview on 01453872266 , emailing info@nuview-ltd.com or visiting www.nuview.co.uk.
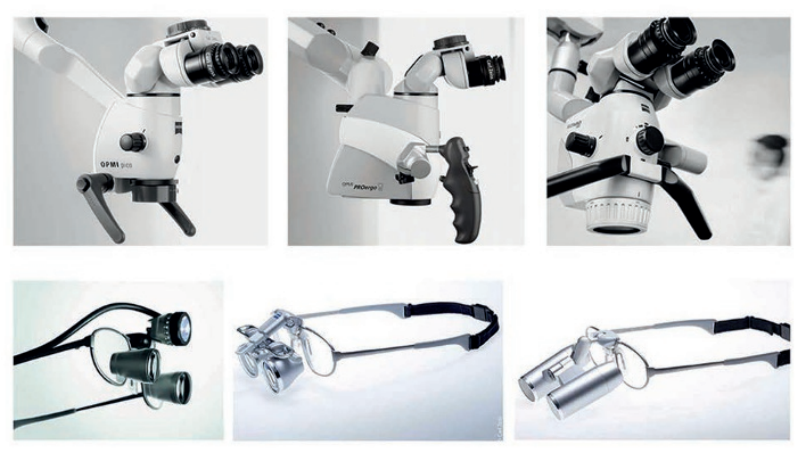

\section{New addition to the decontamination} experts' family

At this year's BDIA Dental Showcase 2018, visit decontamination experts EschmannDirect on stand M10 for the best disinfection and sterilisation equipment. Eschmann will be introducing a brand new 'Little Sister' steriliser that builds on the unrivalled technology of market leading products such as the SES3000B and SES 2010. It represents the next generation of decontamination equipment.

The state-of-the-art solution will be available alongside Lifetime Breakdown Warranty, Care \& Cover Protection, complimentary training and more for complete peace of mind and compliance.

To find out more, visit Stand M10 or visit www.eschmann. co.uk or call 01903 753322 .

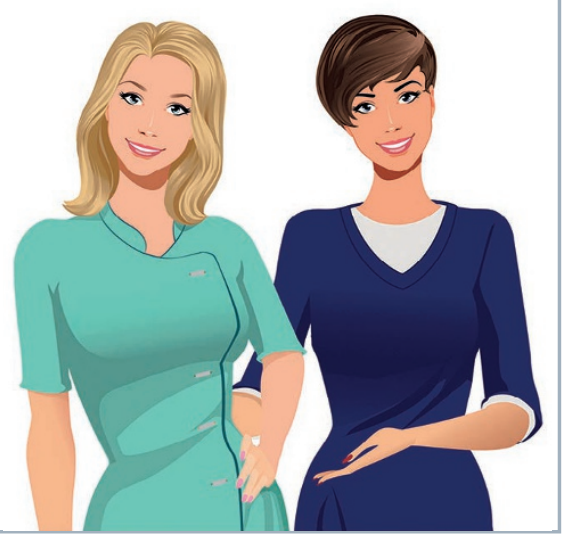

